\title{
Impact of Fear of Missing Out on Psychological Well-Being Among Emerging Adulthood Aged Social Media Users
}

\author{
Judithya Anggita Savitri1 \\ ${ }^{1}$ Department of Psychology, Universitas Negeri Yogyakarta, \\ Jl. Colombo No. 1 Karang Malang Sleman, Yogyakarta \\ 1 judithya.anggita2015@student.uny.ac.id
}

\begin{abstract}
This study aimed to find out the impact of Fear of Missing Out (FoMO) FoMO on psychological well-being especially for social media users at the age of emerging adulthood. This study used a quantitative correlational research. The research was conducted through online questionnaire invloving 400 people obtained through accidental sampling method. The data collected using a fear of missing out (FoMO) scale and a psychological well-being scale that had been modified from Przybylski's FoMO scale and Ryff's Psychological well-being scale. The FoMO scale consists of 15 items with good reliability estimation $(\alpha=0.849)$ and the psychological well-being scale consists of 45 items with also a good reliability estimation $(\alpha=0.941)$. The data was analyzed using the simple linear regression. The anlysis revealed that FoMO was able to predict psychological well-being $(\mathrm{F}=43,753 ; \mathrm{p}=0,000<\alpha 0,05)$. FoMO can predict psychological well-being with a contribution value of $9,99 \%$. The regression equation line obtained was $\mathrm{Y}=154,264-0,633 \mathrm{X}$. Further discussion regarding the impact of fear of missing out on psychological well-being among emerging adulthood aged social media users were elaborated.
\end{abstract}

Keywords: fear of missing out; psychological well-being; emerging adulthood

\section{Introduction}

Psychological well-being is one thing that everyone covets. Ryff (1995) described psychological well-being as a person's ability to recognize and develop themselves in accordance with their potential. Ryff (1989) added, a person can be said to have psychological well-being when that person can function positively psychologically. Furthermore, Ryff and Singer (2008) argued that individuals with high psychological well-being will be more productive and have better mental and physical health than individuals whose psychological well-being is low. Huppert (2009) asserts that psychological well-being is associated with flexible and creative thinking, prosocial behavior, and good health.

However, based on data obtained from the World Health Organization (WHO) the number of people living with mental disorders increased by more than
18\% between 2005 and 2015. Supported by a statement from the Ministry of Health of the Republic of Indonesia (2016) which says that mental health is still one of the significant health problems in the world, including in Indonesia. Data on Basic Health Research (RISKESDAS) in 2013 shows the prevalence of mental emotional disorders as indicated by symptoms of depression and anxiety for the age of 15 years and over reaching around 14 million people or $6 \%$ of Indonesia's population. This is an indication that there are still many individuals with low psychological wellbeing.

Data obtained from the results of the Twenge survey (2018) adds to the fact that from 2008 to 2017, the level of individuals reporting depressive symptoms increased by $63 \%$ in young adults aged 18 to 25 years. The percentage of young adults 


\section{Impact of Fear of Missing Out on Psychological Well-Being \\ Judithya Anggita Savitri}

experiencing serious psychological distress also increased by $71 \%$. Similar trends also shown in suicidal thoughts among young adults that increased by $47 \%$.

One of the factors that contributed to the low psychological well-being according to Przybylski, Murayama, DeHaan, and Gladwell (2013) was Fear of Missing Out or commonly referred to as FoMO. Beyens, Erison, and Eggermont (2016) support this argument by saying FoMO is a sign of a negative psychological well-being. The negative sign was due to the feelings of fear, anxiety, and worry that result from the presence of FoMO renders an individual unable to control the environment, establish positive relationships with others, and have low self-acceptance.

FoMO is defined as the fear that someone will lose social opportunities, thus encouraging that person to always be continuously connected with others and follow the latest news about everything that other people do (Przybylski et al., 2013). These feelings of fear, anxiety, and worry cause individuals to experience difficulties in controlling the environment, establishing positive relationships with others, and accepting themselves (Beyens et al., 2016). Studies show that people who face FoMO are more likely to fall prey to psychological demands to stay connected and to make connection with others (Beyens et al., 2016), thus participating in social media becomes a necessity for them. Research by Przybylski et al. (2013) also revealed that people with high level of FoMO usually are at a younger age and reporting a lower moods and lower life satisfaction in general. Pryzbylski et al. (2013) stated that people with FoMO were more likely to check their smart phones as soon as they wake up in the morning, right before they go to sleep, even when they drive.

This phenomenon was closely related to the use of social media in this digital age, where most people are certainly familiar with social media. Thanks to social media, communication can be established without being limited by distance and time. Social media provides a space for someone to actively communicate with others and made it easy for individuals to acquire new information (Burke, Marlow \& Lento, 2010).

Social media is a web-based service that allows users to create a public or a semi-public profile within a system; display other users related to him; and observe the list of networks they have and the list made by other users in the system (Boyd \& Ellison, 2008). Nowadays, social media attracts people's attention because it can be used as an easy and important means to maintain social relationships and to satisfy one's social needs (Shapiro \& Margolin, 2014). This causes social media to be an inseparable part in many things in life (Lenhart, 2015). But behind the popularity of social media, it also has its' own positive and negative impacts. Using social media wisely can lead to positive impacts, such as easily getting health information from medical experts; getting emotional support; forming community; etc. (Royal Society for Public Health, 2017). Conversely, maladaptive use of social media can lead to negative impact. According to Oberst, Renau, Chamarro and Carbonell (2016) the use of maladaptive social media can have a negative impact on the well-being and psychological functioning of children, adolescents, and early adults. In line with this opinion, Twenge (2018) asserts that the use of social media is likely to be the cause of increasing mental health problems in young adults.

Regarding trends in the use of social media in Indonesia, according to a statement by the secretary general of the Indonesian Internet Service Providers Association (APJII) in 2017 Indonesia experienced a growth of internet users by $54.6 \%$. The most accessed internet content is social media content, where $97.4 \%$ of Indonesians access social media while using the internet (Sugiharto, 2016). 


\section{Impact of Fear of Missing Out on Psychological Well-Being Judithya Anggita Savitri}

Social media users come from various stages of age, however Sugiharto (2016) points out that internet users in Indonesia are dominated by young people around 20 to 24 years. Around 22.3 million internet users were found aged around this range, most of whom access social media while using the internet. Quoted from liputan6.com, the Indonesian Internet Service Providers Association (APJII) released data stating that the majority of respondents claimed to access the internet for more than six hours every day. There are around $55.39 \%$ of the total respondents who access the internet more than six hours every day. While other respondents vary from 2 to 6 hours a day.

People around 20 to 24 years age are categorized as emerging adulthood. During this stage, an individual may face new goals and tasks that involve other people directly for the first time, thus they are expected to not only develop and achieve their personal goals, but also start a new developmental process by forging relation with others (Salkind, 2006). However, result from a study by Azka, Firdaus and Kurniadewi (2018) revealed that individuals in emerging adulthood also have a high vulnerability to social media dependency, because they tend to be less stable in managing their needs for life, interpersonal relationships, and developing both affective and cognitive aspects. So, when individuals get into difficulties during their developmental process, they tend to escape through the intensive use of social media.

Based on the description above, it can be summarized that emerging adult are expected to build positive relationships with others. In the other hand, they also have vulnerabilities to the intensive use of social media and experiencing FoMO which can lead to low positive relationships with others, that in turn contribute to the worsening of their psychological well-being. While this issue is certainly important, not many researchers has looked into FoMO. This research will answer those issue by understanding the impact of fear of missing out on psychological well-being among emerging adulthood aged social media users.

\section{Methods}

\section{Research Design}

This research is a correlational research. The variables of this resarch are: Fear of Missing Out as predictor, and Psychological Well-being as criterium. This research was conducted in March to April 2019 through online questionnaire constructed using google form.

\section{Participants}

The population of this study is the users of social media aged 18-25 years in Yogyakarta amounting to 289,900 people according to Yogyakarta Bureau of Statistics. We determined 400 people as our sample, that was obtained using accidental sampling technique.

\section{Research Procedure and Intruments}

Data was collected through online questionnaire that consists of two scales, the FoMO scale that was modified from Przybylski (2013) Fear of Missing Out Scale and psychological well-being scale modified from Ryff (1995) Psychological Well-being Scale.

The four indicators of fear of missing out are worries, anxiety, fear, and the desire to stay connected with others. Individuals who have a high fear of missing out are characterized by high score on each indicator.

The psychological well-being consists of six dimensions: self-acceptance, positive relations with others, autonomy, environmental control, life goals, and selfdevelopment. Individuals with high level of psychological well-being will exhibit high self-acceptance, having positive relations with others, high autonomy, have the ability to control the environment, have 


\section{Impact of Fear of Missing Out on Psychological Well-Being \\ Judithya Anggita Savitri}

purposeful life goals and good selfdevelopment.

\section{Data Analysis}

Data analysis techniques used in this study consisted of descriptive analysis, analysis prerequisite test consisting of normality and linearity tests, and hypothesis testing.

\section{Descriptive Analysis}

Both of the scale uses likert scale with four options (1-4), four being very suitable and one being very unsuitable. The total score of each scale will be categorized into five categories. Categorization is done by using manual calculations.

Table 1.

Norm for Categorization According to Azwar (2012)

\begin{tabular}{cc}
\hline Very low & $\mathrm{X} \leq \mu-1,5 \sigma$ \\
\hline Low & $\mu-0,5 \sigma<\mathrm{X} \leq \mu-1,5 \sigma$ \\
\hline Average & $\mu-0,5 \sigma<\mathrm{X} \leq \mu+0,5 \sigma$ \\
\hline High & $\mu+1,5 \sigma<\mathrm{X} \leq \mu+0,5 \sigma$ \\
\hline Very High & $\mathrm{X}>\mu+1,5 \sigma$ \\
\hline
\end{tabular}

\section{Hypothesis Testing}

To test our hypothesis, we employ simple regression analysis with the help of the SPSS for Windows. The analysis was performed to determine the effect of a predictor variable on a criterion variable. Simple regression test was chosen because in this study consisted of one predictor variable $(\mathrm{X})$ and one criterion variable $(\mathrm{Y})$. The result of the analysis was then put into linear regression equation using the formula $\mathrm{Y}=\mathrm{a}+\mathrm{b} . \mathrm{X}$.

\section{Findings and Discussion}

The data was obtained from 400 people aged 18-25 who used social media. Descriptive analysis is calculated by means of manual calculation based on Azwar's (2012) categorization norms.
Tabel 2. Result Categorization of FoMO Scale

\begin{tabular}{lcc}
\hline & Category & Perce \\
\hline Very High & $>49$ & $5,5 \%$ \\
High & $43-49$ & 24,75 \\
Average & $35-42$ & $43,5 \%$ \\
Low & $28-34$ & $18 \%$ \\
Very Low & $<27$ & $8,25 \%$ \\
\hline & Total & $100 \%$ \\
\hline
\end{tabular}

Based on Table 2 it is revealed that most of the participants were in the average category ( $\mathrm{n}=43.5 \%$ ), with the least in the very high category $(\mathrm{n}=5.5 \%)$.

Tabel 3. Result Categorization of Psychological Well-being Scale

\begin{tabular}{lcc}
\hline & Category & Percenta \\
\hline Very High & $>154$ & $7 \%$ \\
High & $140-154$ & $21 \%$ \\
Average & $124-139$ & $40 \%$ \\
Low & $108-123$ & $26 \%$ \\
Very Low & $<107$ & $6 \%$ \\
\hline \multicolumn{2}{c}{ Total } & $100 \%$ \\
\hline
\end{tabular}

Based on Table 3, it is revealed that the most of the participants were in the average category $(n=40 \%)$, with the least in the very low category $(n=6 \%)$. F test results revealed $\mathrm{F}$ value of 43.753 ; ( $\mathrm{p}=$ $0,000 ; \mathrm{p}<0.05)$, which means that the predictor (X) can actually predict the criterium variable $(\mathrm{Y})$. Further analysis revealed R2 of 0.099 which means the effective contribution of variable $\mathrm{X}$ to the variable $\mathrm{Y}$ is $99 \%$.

The analysis supports our hypothesis that FoMO can be a predictor of psychological well-being in emerging adulthood social media users. The higher the FoMO, the lower the level of psychological well-being of emerging adult users of social media. Conversely, the lower the level of FoMO, the higher the level of 
psychological well-being of emerging adult users of social media.

Discussion

The factor that causes individuals to tend to have low psychological well-being when having FoMO in this study is due to the use of social media. Other factors that also influence psychological well-being in addition to social media, according to the opinion of Huppert (2009) are the age and gender stages. According to Huppert (2009) women are likely to have lower psychological well-being than men so that they are more likely to have mental disorders, so the majority of respondents in this study who are female also influence the outcome of psychological well-being and FoMO. Another factor is age, according to Huppert (2009) that the psychological wellbeing score of individuals in middle age is lower than individuals in young or old age, so that the subject of this study at the stage of emerging adulthood also affects the psychological welfare outcomes and FoMO.

Individuals who experience FoMO tend to feel stress to fear when unable to connect with social media (Beyens, et al., 2016). Anxiety then affects the psychological well-being of individuals, especially in aspects of environmental mastery, positive relationships with others and self-acceptance (Beyens, et al., 2016). Therefore, someone with a high FoMO level tends to have lower psychological well-being compared to someone who does not have FoMO or only has a low FoMO level.

The era of emerging adulthood is an important period for individuals to prepare for adult life (Arnett, 2000). At this time individuals face the task of forming intimate relationships with others (Erikson in Papalia, 2012). Therefore, at this time someone ideally establish relationships with others and explore themselves. Social media then becomes one of the tools to facilitate individuals in establishing relationships and exploring themselves. However, social media is also a means for the spread of the phenomenon of FoMO to watch out for.

The results of this study indicate that individuals who use social media, especially those in the era of emerging adulthood, need to be aware of the potential negative impacts that may result from unwise use of social media. The unwise use of social media also contributes to reducing the level of psychological well-being. On the other hand, psychological well-being is important for emerging adulthood individuals to prepare for the next period. Unwise use of social media can result in individuals having difficulties in preparing their adult life in a psychologically healthy state.

The analysis shows that the FoMO variable has a negative influence on the psychological welfare variable with a contribution of $9.9 \%$. This indicates that there is an effect of $9.9 \%$ between FoMO and psychological well-being. This is because FoMO is not a major factor in the formation of psychological well-being, another $90.1 \%$ is influenced by various factors; personality (extraversion or neuroticism); age; gender; level of education; economic inequality; social media. FoMO is part of social media which then contributes to the low psychological well-being. In other words, FoMO can be one of the causes of the low psychological well-being of individual social media users in the era of emerging adulthood.

The results of this study also indicate a relationship between FoMO and each dimension in psychological well-being. Correlation test results between the dimensions of psychological well-being with FoMO are as follows:

There is a negative and significant relationship between FoMO and selfacceptance dimensions. This is in line with research by Beyens, et al. (2016) which states that FoMO is associated with anxiety and people with FoMO will tend to have 
difficulty accepting themselves. People with high FoMO will feel anxious or worried about the activities carried out by other people and feel that things done or owned by others are more pleasant than what they have or experienced. Thus, someone with a high FoMO can be said to be dissatisfied with himself and tends to want to be someone else.

There is a negative and significant relationship between FoMO with the dimensions of positive relations with others. This is in line with research by Beyens, et al. (2016) which says that individuals with FoMO tend to have difficulty in undergoing positive relationships with others. According to Luckerson (2015) something like this happens because today, social media and internet usage affect the way people live their lives, especially in communication. Luckerson (2015) added that lately, meetings that should be a place for people to interact and talk to build bonds have turned into meetings where most people prefer to open social media through their devices rather than interacting with each other. In other words, someone with a high FoMO is more focused on what is happening on his social media than establishing a warmer relationship with others through direct talks. Someone with FoMO tries to communicate and connect with other people, but there is no warm, satisfying, and trusting relationship in the relationship.

There is a negative and significant relationship between FoMO and the dimension of autonomy. Someone with high FoMO will tend to have low independence and be easily influenced by the social environment. This is in line with FoMO's research in economics which lately utilizes FoMO's feelings to be able to carry out effective sales strategies. According to Anggraini (2014), fear of being left behind from the social environment is a form of psychological need that is able to motivate consumers, to do something they think can reduce these fears. In addition, someone with a high FoMO tends to seek acceptance and recognition from others rather than evaluating themselves by personal standards. This relates to the need to be accepted which then causes people with FoMO to do everything they can to be socially acceptable. This is supported by the results of JWT Intelligence research (2012) in which $90 \%$ of respondents claimed to be happy to be the people who know the most information, so that they can be more accepted and recognized in their social environment.

There is a negative and significant relationship between FoMO and the dimension of environmental mastery. This is in line with research by Reyes et al. (2018: 511) which says that FoMO can lead to the emergence of Problematic Internet Use (PIU). Spada (2014) describes PIU as the inability of individuals to control their behavior in internet usage which can then lead to unintended consequences. Someone with high FoMO tends to have a low ability to control the environment because they do not have the ability to master and regulate their environment (Ryff, 1995).

There is a negative and significant relationship between FoMO and life purpose dimensions. Someone with high FoMO tends to not have a sense of direction and purpose in life. This is in accordance with the statement of Przybylski (2013) which says that someone with FoMO tends to have low satisfaction in fulfilling their basic psychological needs so that they only focus on meeting those needs.

There is a negative and significant relationship between FoMO and selfdevelopment. Someone with high FoMO tends to have difficulty developing new attitudes or behaviors to develop in a better direction. This is consistent with Alt's (2015) research which found that someone with a high FoMO tends to not have the motivation to learn. 


\section{Impact of Fear of Missing Out on Psychological Well-Being \\ Judithya Anggita Savitri}

\section{Conclusion}

Based on research that has been done, it can be concluded that there is a negative relationship between Fear of Missing Out (FoMO) and psychological well-being of social media users at the age stage of emerging adulthood in DIY. This means that when a person has a low level of FoMo, he will have a psychological wellbeing that tends to be high. Conversely, when someone has a high level of FoMO, then he will have psychological well-being that tends to be low.

\section{References}

Azka, F., Firdaus, D.F., \& Kurniadewi, E. (2018). Kecemasan sosial dan ketergantungan media sosial pada mahasiswa. PSYMPATHIC: Jurnal Ilmiah Psikologi Vol. 5, No.2, 2018: 201-210.

Beyens, I., Frison, E., \& Eggermont, S. (2016). 'I don't want to miss a thing': adolescents' fear of missing out and it's relationship to adolescents' social needs, facebook use, and facebook related stress. Computers in Human Behavior, 64, 1-8.

Boyd, D.M. \& Ellison, N.B. (2008). Social Networks sites: definition, history, and scholarship. Journal of Computer- Mediated Communication 13 (2008) 210-230.

Burke, M., Marlow, C., \& Lento, T. (2010). Social network activity and social well- being. Postgraduate Medical Journal, 86, 455-459.

Huppert, F. A. (2009). Psychological wellbeing: evidence regarding its causes and consequences. Applied Psychology: Health and Well-Being, 1(2), 137-164.

JWT Intelligence. (2012). Fear of missing out (fomo). Diakses dari http://www.jwtintelligence.com/wp-
content/uploads/2012/03F_JW'T_F

oMO_update_3.21.12.pdf

Kesehatan, K., \& RI, K. K. (2013). Riset kesehatan dasar. Jakarta: Badan Penelitian dan Pengembangan Kesehatan Departemen Kesehatan Republik Indonesia.

Lenhart, A. (2015). Teens, social media and technology overview. Washington DC: Pew Internet \& American Life Project.

Luckerson, V. (2014). Fear, misinformation, and social media complicate Ebola fight. Time. Retrieved from http://time.com/3479254/ebolasocial-media/

Luna, K. (2014). The psychology of fomo. Diambil dari: http://youbeauty.com/life/thepsychology-of-fomo/

Oberst, U., Renau, V., Chamarro, A., \& Carbonell, X. (2016). Gender stereotypes in facebook profiles: are women more female online? Computers in Human Behavior, 60, 559-564.

Papalia, D.E., Olds, S.W., \& Feldman, R.D. (2007). Human development 10th ed. New York:McGraw Hill Companies.

Przybylski, A.K., Muryama, K., DeHaan, C.R., \& Gladwell, V. (2013). Motivational, emotional, and behavioral correlates of fear of missing out. Computers in Human Behavior, 29, 1841-1848.

Putra, A.D. (2018). Hubungan antara fear of missing out dengan kesejahteraan psikologis pengguna instagram pada masa transisi menuju dewasa. Published Bachelor Thesis, Universitas Sanata Dharma, Yogyakarta.

Reyes, M.E.S. \& Cayubit, R.F.O. (2018). Fear of missing out and its link with 
social media and problematic internet use among Filipinos. North American Journal of Psychology December 2018.

RSPH. (2017) Social media and young people's mental health and well being. Diambil dari https://www.rsph.org.uk/orgwork/policy/social-media-andyoung-people-s-mental-health-andwellbeing.html

Ryff, C.D. (1989) Happiness is everything, or is it? explorations on the meaning of psychological well being. Journal of Personality and Social Psychology., 57(6), 1069.

Ryff, C.D. (1995). Psychological well-being revisited: advances in the science and practice of eudaimonia. Psychotherapy and Psychosomatics, 83, 10-28.

Ryff, C.D., \& Singer, B. (2002). From social structure to biology. Handbook of Positive Psychology, 63-73.

Salkind, N.J. (2010). Encyclopedia of human development. USA: Sage Publications, Inc.

Shapiro, L.A.S., Margolin, G. (2013). Growing up wired: social networking sites and adolescent psychosocial development. Clinical Child and Family Psychology Review, 17(1).

Spada, M. (2014). An overview of problematic internet use. Addictive Behaviors, 39(1), 3-6.

Sugiharto, B.A. (2016). Pengguna internet di indonesia didominasi anak muda. CNN Indonesia. Retrieved from: http://cnnindonesia.com/teknologi/ 20161024161722-

185167570/pengguna-internet-diindonesia-didominasi-anak-muda

Twenge, J.M., Martin, G.N., \& Campbell, W.K. (2018). Decreases in psychological well- being among
American adolescent Rafter 2012 and links to screen time during the rise of smartphone Technology. Emotion, 18(6), 765-780. 